\title{
Heavy metal pollution index for assessment of seasonal groundwater supply quality in hillside area, Kalasin, Thailand
}

\author{
Chuthamat Chiamsathit $^{1}$ (D) - Supunnika Auttamana ${ }^{1} \cdot$ Surasak Thammarakcharoen $^{1}$
}

Received: 18 July 2019 / Accepted: 7 May 2020 / Published online: 20 May 2020

(c) The Author(s) 2020

\begin{abstract}
Agriculture is a major activity in most rural areas in northern Thailand. The aim of this study was to assess the heavy metal pollution index (HPI) for water supply quality in a rural village in Kalasin Province named Kaeng Ka-am village located in the hillside area of Phu Phan mountain. The concentration of heavy metals including iron (Fe), manganese (Mn), and zinc $(\mathrm{Zn})$ in groundwater supply has been analyzed by the atomic absorption spectrometer. The groundwater supplied samples were collected from eight different locations in and around the region which covers agricultural and municipal area during the monsoon and post-monsoon seasons. The results were evaluated in accordance with the drinking water quality standards suggested by the World Health Organization and Thailand Department of Health Standards. Most of the samples were found within limit except for Fe and Mn contents during the monsoon season at three sampling locations which is above the desirable limit, i.e., $0.3 \mathrm{mg} / \mathrm{L}$. The mean values of HPI were 70 and 46 in the monsoon and the post-monsoon season, respectively, and these values are well below the critical index limit of 100 .
\end{abstract}

Keywords Heavy metal pollution index (HPI) · Water supply $\cdot$ Permissible limit · Concentration · Preliminary treatment

\section{Introduction}

Clean and safe water is necessary for human life. Water supply quality is a very important factor, and also it indicates the quality of life. Groundwater is the majority source of water supply for domestic, agricultural, and industrial sectors in many countries (Beyene 2015). In Thailand, groundwater has been selected as one of the purest forms of water available for water requirement of people who live in rural and semi-urban areas, especially hillside area. The groundwater quality directly relies on the infiltrated water, precipitation, surface water, and subsurface geochemical processes (Jafar et al. 2013). Water discharge from human activities also directly affects the quality of the groundwater (Vasanthavigar et al. 2010). The pollution of groundwater by hazardous or heavy metals is a serious issue because these metals are permanent and most of them have toxic effects on living organisms for human consumption when they exceed the permissible limit (Sirajudeen et al. 2014; Chakraborty et al.

Chuthamat Chiamsathit

aum_chuthamat@hotmail.com

1 Faculty of Sciences and Health Technology, Kalasin University, Na Mon, Kalasin 46230, Thailand
2009). Heavy metals are one of the major environmental issues, occurrence in waters from naturals such as chemical weathering of minerals and soil leaching (Biswas et al. 2017). The main anthropogenic sources of heavy metal contamination are industrial and municipal effluents and runoff from heavy metal-containing fertilizer and pesticides in agricultural lands (Pradip et al. 2017).

The contamination of heavy metals in groundwater has been applied for the assessment of clean water for human consumption (Sarala and Uma 2013; Sirajudeen et al. 2014). Recently, many researchers have evaluated heavy metal contamination in groundwater (Zakhem and Hafez 2015; Kumar et al. 2015) and surface water by using the heavy metal pollution index (HPI) (Pradip et al. 2017; Balakrishnan and Ramu 2016; Ardani et al. 2015). Water quality and its suitability for drinking purposes can be examined by determining the HPI index. The heavy metal pollution index has been used by Boulos and Rania (2015) as an effective tool for groundwater quality assessment in Damascus Oasis, Syria. Gurdeep and Rakesh (2017) have also used a HPI model for the seasonal variations in the groundwater quality in and around the Goa mining area during the monsoon and postmonsoon seasons. Groundwater is only the major source of water supply for drinking and household purpose in the 
study area. Therefore, the seasonal assessment of the heavy metal pollution index (HPI) with respect to heavy metal contamination in drinking and household water supply system of Kaeng Ka-am village was studied and presented in this paper.

\section{Methodology}

\section{Study area}

The region covers both agricultural land and residence area. Agriculture is the major activities, and chief crops grown are paddy, cassava, Saccharum, field corn, etc. The study area locates in the Kang Ka-am village in Somdet District, Kalasin, northeastern Thailand (Fig. 1) and covers an area of $128 \mathrm{~km}^{2}$. This area which locates in the hillside area of Phu Phan mountain (Fig. 2) has a semiarid climatic type with temperature ranging from 19 to $45^{\circ} \mathrm{C}$. The water supply system covers around 650 users. Groundwater has been only one source of water supply for drinking and household use water in this area. Most people in the village drink water directly from tap water. The filter tank is only one treatment unit before supplying the water. The treated water is stored in the high tank before distributing it to the users.

\section{Sampling and analysis}

Eight sampling stations were collected from the municipal water supply in Kang Ka-am village (Fig. 3). Three samples at each sampling station were collected directly from tap water for assessment of water supply quality during the monsoon (September 2018) and post-monsoon seasons (December 2018). The first station was at the pumping station where the samples were collected at the entry point of the supply water to the user's house. Other sampling stations were at the users' house. The water samples were collected from the nearest water users of the distribution line in the village, middle, and the farthest which represented the quality of the piped water. Water supply samples were collected in clean polyethylene bottles. At the time of sampling, bottles were thoroughly rinsed 2-3 times with water at its source to be sampled. The water samples were collected after flushing water for about $2-3 \mathrm{~min}$ to remove the stagnant water as per standard procedures (American Public Health Association 2014). The collected water samples were transported to the laboratory on the same day and preserved in a refrigerator at $4{ }^{\circ} \mathrm{C}$ before analysis. Some physical parameters were tested namely $\mathrm{pH}$, total hardness, total dissolved solids. Hydrogen ion concentration $(\mathrm{pH})$ was measured on the site by using a digital $\mathrm{pH}$ meter while other parameters were determined

Map of Somdet district in Kalasin Province, Thailand

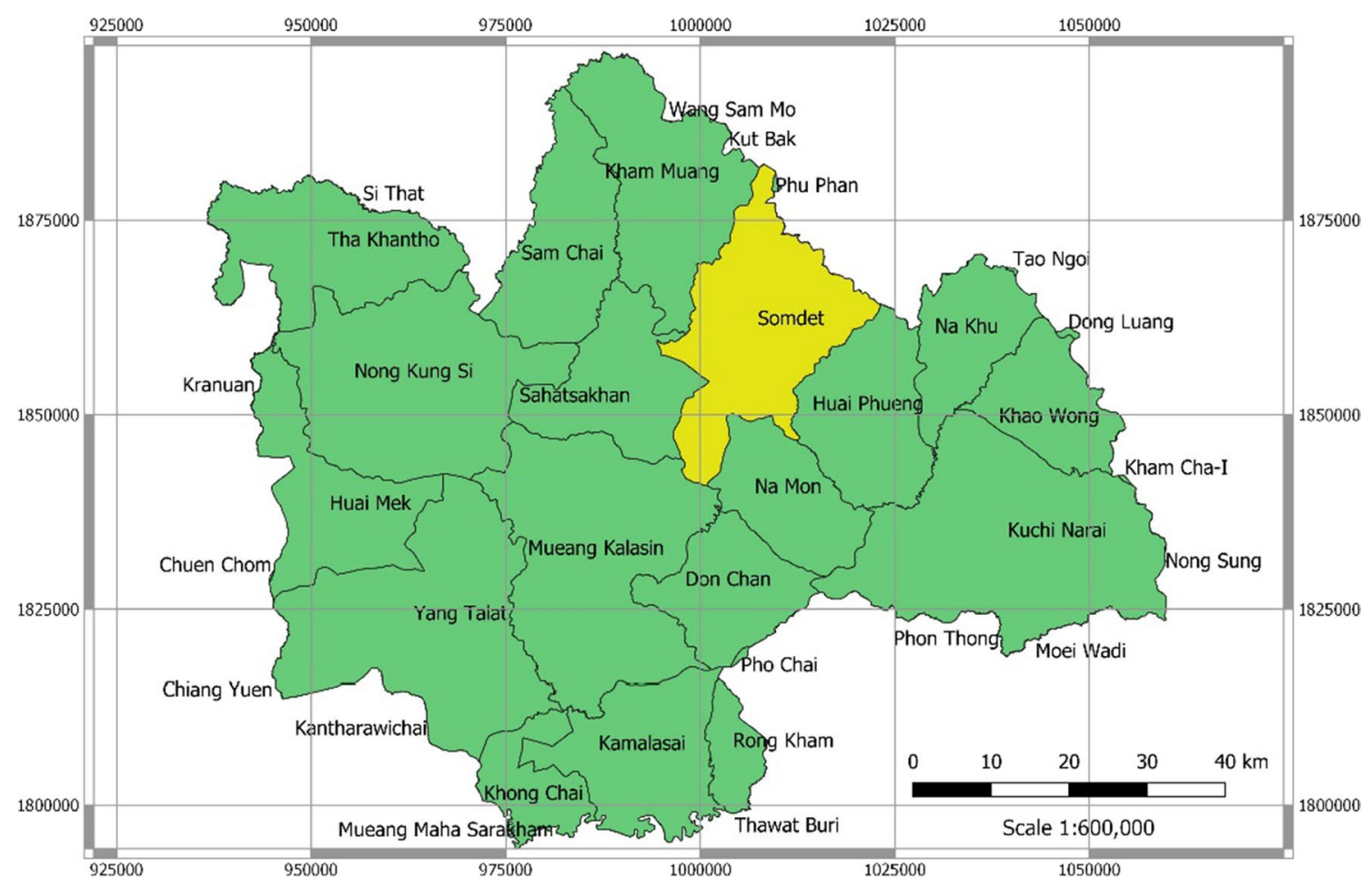

Fig. 1 Map of Kalasin Province 


\section{Location of Kang Ka-am village}

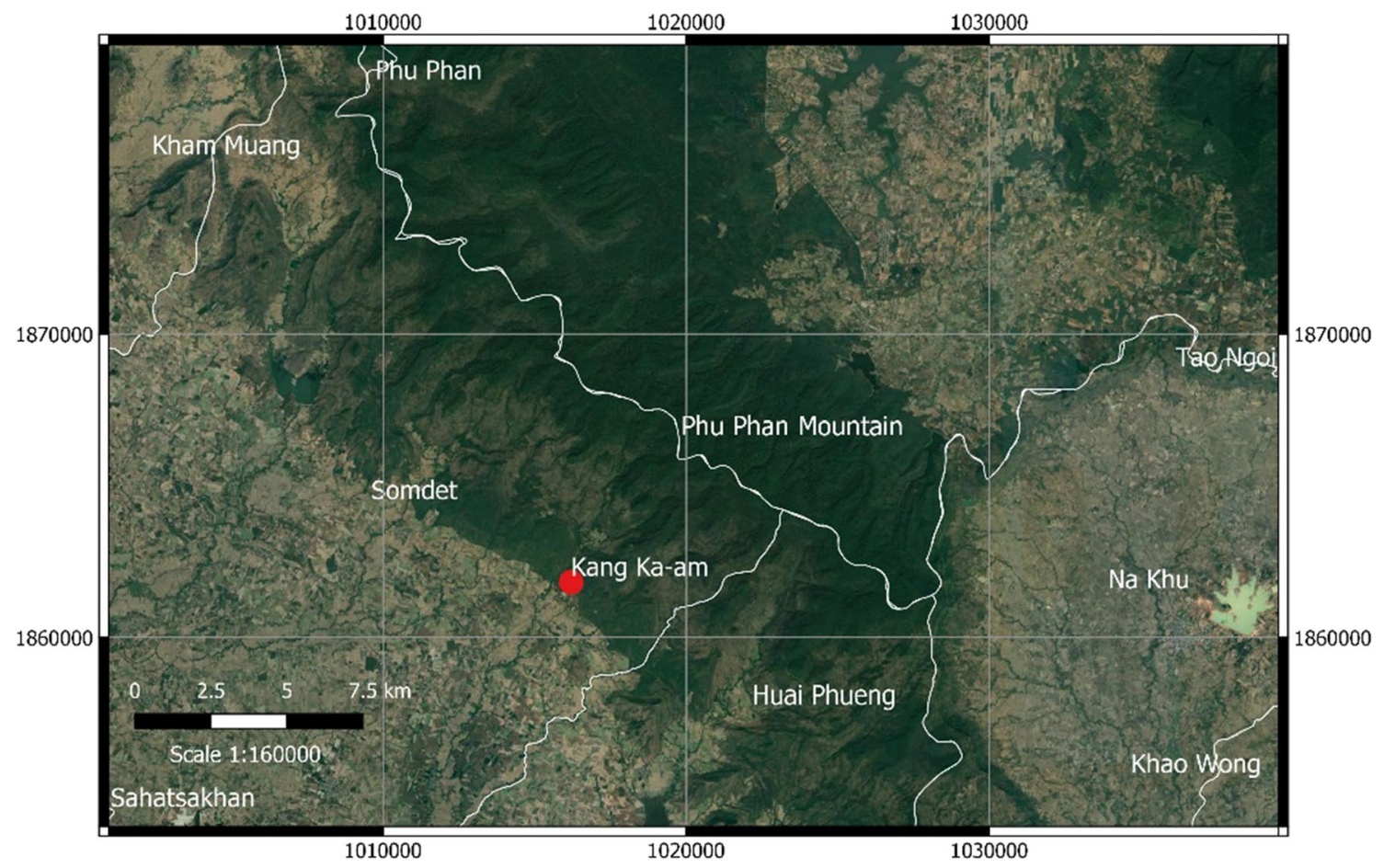

Fig. 2 Location of Kang Ka-am village

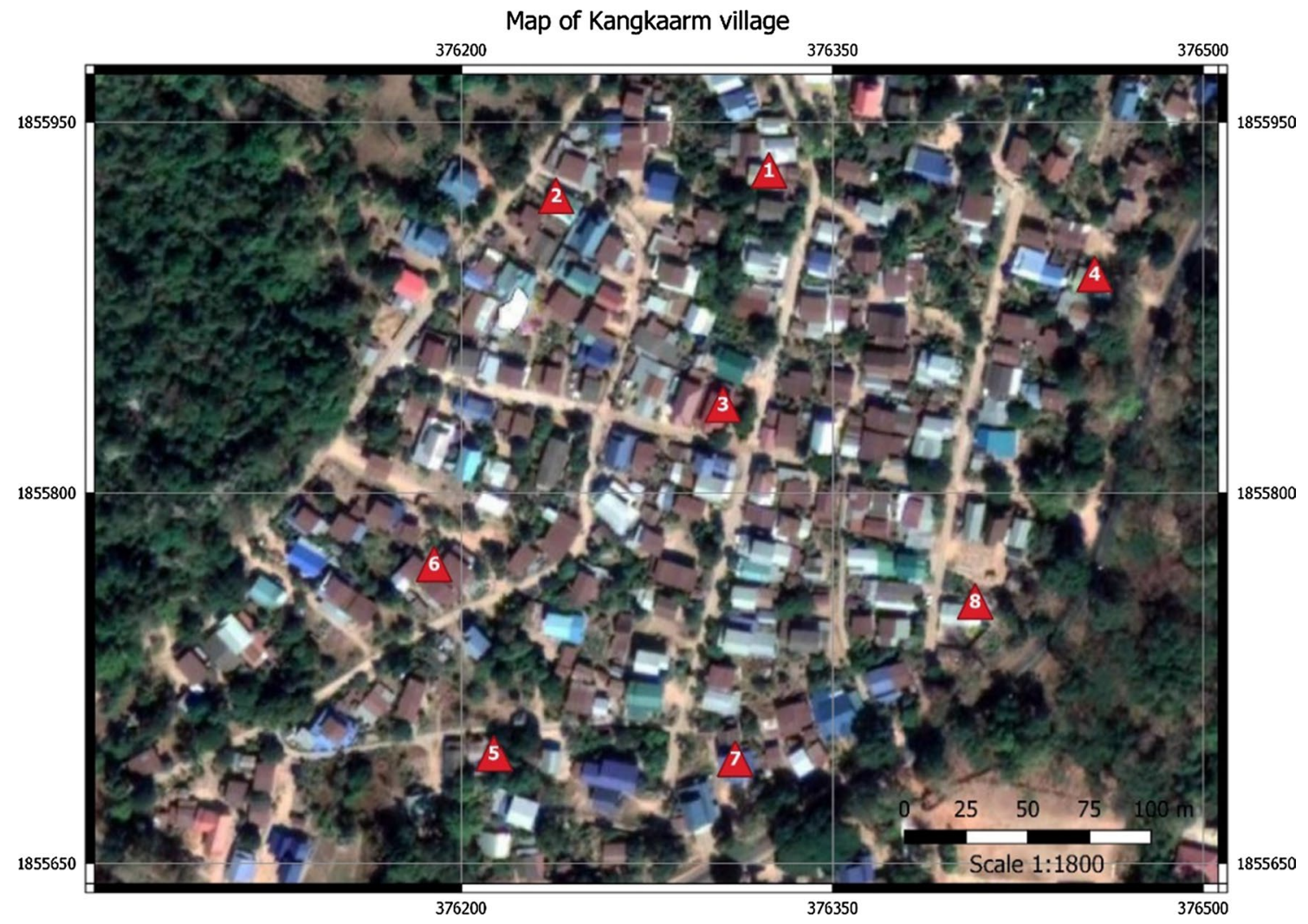

Fig. 3 Eight sampling stations at Kang Ka-am village in Somdet district, Kalasin, Thailand

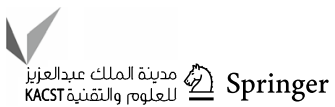


in the laboratory within 48-72 $\mathrm{h}$ of the sampling following the standard methods (American Public Health Association 2014). The standard methods of Water and Wastewater standards (American Public Health Association 2014) were used for the analysis of the various physicochemical parameters. Total dissolved solid (TDS) was carried out by gravimetric analysis. Total hardness (TH) was measured by volumetric titration methods. Heavy metals such as iron $(\mathrm{Fe})$, manganese $(\mathrm{Mn})$, and zinc ( $\mathrm{Zn})$ were also analyzed by using atomic absorption spectrophotometer (AAS) (model: PerkinElmer PinAAcle 900F Atomic Absorption Spectrometer). The chemical analysis of water samples was carried out in the laboratory of the faculty of science and health technology at Kalasin University.

\section{Heavy metal pollution index (HPI)}

The heavy metal pollution index is a useful method for assessing the combined influence of individual heavy metal indicators on the overall water quality (Reza and Singh 2010) and a view of the suitability of groundwater for human consumption (Rizwan et al. 2011). HPI is a calculation of rating that shows the composite influence of individual heavy metal on the overall water quality (Sheykhi and Moore 2012). The HPI method was developed by assigning a rating or weightage $\left(W_{i}\right)$ for each chosen parameter. The rating is an arbitrary value between zero and one, reflecting the relative importance of individual quality consideration. In this study, the limit of concentration (i.e., the highest permissible value for water supply, $S_{i}$ ) used the international standards (WHO). In computing the HPI, Prasad and Bose (2001) considered unit weightage $\left(W_{i}\right)$ as a value inversely proportional to the recommended standard $\left(S_{i}\right)$ of the corresponding parameter as proposed by Reddy (1995). The HPI is calculated with the following equation:

$\mathrm{HPI}=\frac{\sum_{i=1}^{i=n}\left(Q_{i} \times W_{i}\right)}{\sum_{i=1}^{i=n} W_{i}}$

where $W_{i}$ is the unite weight of $i$ th parameters, $Q_{i}$ is the subindex of the $i$ th parameter, $n$ is the number of parameters considered. Weighted arithmetic index method has been used for calculation of HPI.

The subindex $\left(Q_{i}\right)$ is calculated by

$Q_{i}=\frac{V_{i}}{S_{i}} \times 100$

where $V_{i}$ and $S_{i}$ are the monitored heavy metal concentration and standard permissible values of the $i$ th parameter, respectively. The HPI value indicates the level of heavy metal pollution as shown in Table 1. The critical pollution index value for drinking water must be less than 100 . If the samples have
Table 1 Evaluation of heavy metal pollution, HPI value (Sobhanardakania et al. 2016)

\begin{tabular}{lc}
\hline Degree of pollution & HPI value \\
\hline Low heavy metal pollution & $<100$ \\
Heavy metal pollution on the threshold risk & $=100$ \\
High heavy metal pollution & $>100$
\end{tabular}

heavy metal pollution index values greater than 100 , water is not potable (Balakrishnan and Ramu 2016).

\section{Results and discussion}

\section{Physical parameter analysis}

Physical parameters including $\mathrm{pH}$, total dissolved solid (TDS), and total hardness were measured in the water supply samples. The physical parameters and heavy metal concentrations of water supply samples during the monsoon and post-monsoon seasons are summarized in Table 2. The guideline values as specified by the WHO (2011) and the Thailand Department of Health Standards, TDH (2009) for drinking water quality were used to analyze the results. Table 3 presents a summary of descriptive statistics of the physical parameters and the metal concentrations in the water supply samples $(\mathrm{mg} / \mathrm{L})$.

The $\mathrm{pH}$ of the groundwater samples was found to be ranged between 4.7 and 5.5 and with a mean of 5.0 for the monsoon season, while the post-monsoon season water samples varied from 5.0 to 5.3 and with a mean 5.2, clearly indicating acidic to slightly alkaline nature of the groundwater samples in both the seasons. In the monsoon and post-monsoon seasons, all $100 \%$ of the groundwater supply samples have a value lower than the desirable limit of 6.5 , as per guideline values of WHO (2011) and 7.0, as per Thailand Department of Health Standards of drinking water. The low $\mathrm{pH}$ of groundwater was also found in the study of Gurdeep and Rakesh (2017) who reported that about $84-87 \%$ of the groundwater samples have a value lower than the desirable limit of 6.5, as per the Indian standard of drinking water.

The total dissolved solid test measures the total amount of dissolved minerals in the water reported that TDS during the monsoon season ranged from 173 to $357 \mathrm{mg} / \mathrm{L}$, with an average of 254. The TDS values during the monsoon season were lower than the values in the post-monsoon season which ranged from 193 to $416 \mathrm{mg} / \mathrm{L}$, with an average of 315 . High TDS levels may cause excessive staining of water pipes and household appliances and can shorten the service life of these appliances (Jafar et al. 2013). 
Table 2 Heavy metal concentrations $(\mathrm{mg} / \mathrm{L})$ and HPI for the individual sampling station

Table 3 Descriptive statistics of the metal concentrations in the water samples $(\mathrm{mg} / \mathrm{L})$

\begin{tabular}{|c|c|c|c|c|c|c|c|c|c|c|c|c|}
\hline \multirow[t]{2}{*}{ Sampling location } & \multicolumn{2}{|l|}{$\mathrm{pH}$} & \multicolumn{2}{|c|}{ TDS (mg/L) } & \multicolumn{2}{|c|}{$\mathrm{Fe}(\mathrm{mg} / \mathrm{L})$} & \multicolumn{2}{|c|}{$\mathrm{Mn}(\mathrm{mg} / \mathrm{L})$} & \multicolumn{2}{|c|}{$\mathrm{Zn}(\mathrm{mg} / \mathrm{L})$} & \multicolumn{2}{|l|}{ HPI } \\
\hline & Rain & Dry & Rain & Dry & Rain & Dry & Rain & Dry & Rain & Dry & Rain & Dry \\
\hline Station 1 & 5.0 & 5.0 & 247 & 287 & 0.20 & 0.16 & 0.21 & 0.14 & 0.10 & 0.09 & 66 & 46 \\
\hline Station 2 & 5.4 & 5.3 & 277 & 335 & 0.19 & 0.16 & 0.44 & 0.14 & 0.47 & 0.07 & 101 & 48 \\
\hline Station 3 & 4.8 & 5.1 & 250 & 312 & 0.26 & 0.15 & 0.10 & 0.15 & 0.07 & 0.08 & 56 & 47 \\
\hline Station 4 & 4.8 & 5.3 & 173 & 223 & 0.19 & 0.13 & 0.13 & 0.16 & 0.09 & 0.06 & 52 & 45 \\
\hline Station 5 & 4.7 & 5.1 & 207 & 315 & 0.18 & 0.10 & 0.12 & 0.16 & 0.13 & 0.07 & 48 & 41 \\
\hline Station 6 & 5.5 & 5.1 & 257 & 318 & 0.41 & 0.10 & 0.10 & 0.16 & 0.16 & 0.05 & 81 & 42 \\
\hline Station 7 & 4.7 & 5.2 & 357 & 416 & 0.38 & 0.13 & 0.15 & 0.15 & 0.13 & 0.06 & 84 & 45 \\
\hline Station 8 & 4.8 & 5.3 & 263 & 314 & 0.24 & 0.12 & 0.20 & 0.20 & 0.11 & 0.07 & 70 & 51 \\
\hline WHO (2011) & $6.5-8.5$ & & 600.00 & & 0.30 & & 0.30 & & 3.00 & & & \\
\hline TDH (2009) & $7.0-8.5$ & & 600.00 & & 0.50 & & 0.30 & & 5.00 & & & \\
\hline
\end{tabular}

\begin{tabular}{|c|c|c|c|c|c|c|c|c|c|c|c|c|}
\hline \multirow[t]{2}{*}{ Sampling location } & \multicolumn{2}{|l|}{$\mathrm{pH}$} & \multicolumn{2}{|c|}{ TDS (mg/L) } & \multicolumn{2}{|c|}{$\mathrm{Fe}(\mathrm{mg} / \mathrm{L})$} & \multicolumn{2}{|c|}{$\mathrm{Mn}(\mathrm{mg} / \mathrm{L})$} & \multicolumn{2}{|c|}{$\mathrm{Zn}(\mathrm{mg} / \mathrm{L})$} & \multicolumn{2}{|l|}{ HPI } \\
\hline & Rain & Dry & Rain & Dry & Rain & Dry & Rain & Dry & Rain & Dry & Rain & Dry \\
\hline Mean & 5.0 & 5.2 & 254 & 315 & 0.3 & 0.1 & 0.2 & 0.2 & 0.2 & 0.1 & 70 & 46 \\
\hline Max & 5.5 & 5.3 & 357 & 416 & 0.4 & 0.2 & 0.4 & 0.2 & 0.5 & 0.1 & 101 & 51 \\
\hline Min & 4.7 & 5.0 & 173 & 223 & 0.2 & 0.1 & 0.1 & 0.1 & 0.1 & 0.05 & 48 & 41 \\
\hline Range & 0.8 & 0.3 & 183 & 193 & 0.2 & 0.1 & 0.3 & 0.1 & 0.4 & 0.05 & 53 & 10 \\
\hline SD & 0.3 & 0.1 & 53 & 53 & 0.1 & 0.0 & 0.1 & 0.0 & 0.1 & 0.0 & 18.2 & 3.3 \\
\hline
\end{tabular}

The optimum range of hardness in drinking water is from 80 to $100 \mathrm{mg} / \mathrm{L}$. Water with hardness above $200 \mathrm{mg} / \mathrm{L}$ may cause scale deposition in the water distribution system and increase soap consumption (Hayelom 2015). The hardness in water is caused by sedimentary rocks and seepage and runoff from soils (Akram and Rehman 2018). Hardness is an important factor for household purposes because pipes can become clogged with scale. However, the results of harness showed that the hardness values were very low or not applicable.

\section{Heavy metal concentration analysis}

In this study, metals that consist of $\mathrm{Fe}, \mathrm{Mn}$, and $\mathrm{Zn}$ were considered. The results in Tables 2 and 3 show that the concentration of iron ( $\mathrm{Fe})$ during the monsoon season varied between 0.2 and $0.4 \mathrm{mg} / \mathrm{L}$ with an average value of $0.3 \mathrm{mg} / \mathrm{L}$ and $25 \%$ of the samples exceeded the permissible limit. High iron concentration may stain plumbing fixtures and clothes and produce undesirable tastes as well as an objectionable reddish brown color to water. All water supply sample concentrations in the post-monsoon season do not exceed the maximum permissible limit of $0.3 \mathrm{mg} / \mathrm{L}$ as specified by the WHO (2011).

Results of the concentration manganese (Mn) show all the water samples in the post-monsoon season listed below the maximum permissible limit. However, a range between 0.10 and $0.44 \mathrm{mg} / \mathrm{L}$ of $\mathrm{Mn}$ concentration during the monsoon season with an average of $0.2 \mathrm{mg} / \mathrm{L}$ (Table 2) and $12.5 \%$ of the samples exceeded the permissible limit of $0.3 \mathrm{mg} / \mathrm{L}$ of Thailand Department of Health Standards (2009) for drinking water and the guideline value WHO (2011). High manganese concentration might cause neurotoxicity and health risk to the rural people due to drinking these contaminated. Manganese occurs naturally in many surface water, groundwater, and food sources. Although manganese is an essential element for humans and animals, excess Mn concentration may cause neurotoxicity, as shown experimentally in neonates given parenteral nutrition (Agency for Toxic Substances and Disease Registry 2012; Erikson et al. 2007).

The concentration of zinc $(\mathrm{Zn})$ in the study area of both seasons varied between 0.05 and $0.5 \mathrm{mg} / \mathrm{L}$, and all the samples have a concentration below $3.0 \mathrm{mg} / \mathrm{L}$ defined by WHO (2011). All samples listed below the maximum permissible limit as specified by the Department of Health Standards (2009) and guideline values of WHO (2011). However, high manganese and iron concentration during the monsoon season exceeded the permissible limit for drinking purposes, in $37.5 \%$ of the stations sampled (at three sampling stations). A higher concentration of Fe $\mathrm{Mn}$ and $\mathrm{Zn}$ during the monsoon is largely controlled by agrochemical fertilizers and pesticides cause the accumulation of $\mathrm{Fe} \mathrm{Mn}$ and $\mathrm{Zn}$ in groundwater. These minerals were commonly found in soil and rock and could dissolve into groundwater as it percolated through soil and rock. 


\section{Analysis of heavy metal pollution index (HPI)}

The HPI values in the study area during the monsoon and the post-monsoon seasons are determined by incorporating the mean concentration values of recorded heavy metals. The details of the HPI calculation for both seasons are presented in Table 4. The mean HPI in the study area of the monsoon and post-monsoon seasons was 70 and 46, respectively. However, the mean HPI in both seasons classified the water samples in the category of low heavy metal pollution (Table 1). HPI was also calculated separately for each individual sampling station (Table 2). The results indicated that the values during the monsoon season were higher than the values in the post-monsoon season (Fig. 4). The results during the monsoon season show that $50 \%$ of the sampling stations have an HPI lower than the mean value of 70 , whereas $12.5 \%$ of the samples during the monsoon season (Fig. 1) reach the limit of high heavy metal pollution (HPI > 100). This indicated the effect of the water treatment system on water supply quality in that region. However, as shown in Fig. 1 all HPI values in the dry season were low heavy metal pollution for all sampling stations and lower than the critical index value for drinking water $(\mathrm{HPI}<100)$.

It was concluded that drinking water in Kang Ka-am village is considered as a good quality only in the dry season $($ HPI $<100)$ with respect to considered heavy metals. The HPI value of one sampling station showed critically polluted with respect to heavy metals (HPI > 100\%) during the monsoon season in this area. The water contained both iron and manganese, staining that could vary from dark brown to black. Therefore, this was sometimes the cause of consumer complaints about red or dirty water. However, this rural village had used natural draft aeration to remove abundant metals contained in groundwater. The frequency of maintenance of the preliminary treatment is important to maintain the efficiency of the aeration and filtration system. The government, therefore, should take the necessary steps and control for mitigating the risk of supply water contamination.

\section{Conclusions}

The present study found that most groundwater supply samples of Kang Ka-am village during the monsoon and post-monsoon seasons were low polluted with respect to heavy metal contamination. The eight sampling stations were collected from the municipal water supply in the village located in the hillside area of Phu Phan Mountain in Kalasin Province. The concentrations of $\mathrm{Fe}, \mathrm{Mn}$, and $\mathrm{Zn}$ were found within limits except for Fe and Mn contents during the monsoon season in few locations which is above the desirable limit recommended for drinking water by the Department of Health Standards (2009) and guideline values of WHO (2011). The almost HPI values of this region groundwater supply quality fall in low heavy metal pollution class (HPI < 100). This indicates the groundwater supply
Table 4 HPI calculation for water sample in the water supply system

\begin{tabular}{|c|c|c|c|c|c|c|c|c|c|c|}
\hline \multirow[t]{2}{*}{ Heavy metal } & \multicolumn{2}{|c|}{$\begin{array}{l}\text { Mean con. } \\
(\mathrm{mg} / \mathrm{L})\end{array}$} & \multirow[t]{2}{*}{$\begin{array}{l}\text { Standard value } \\
(\mathrm{mg} / \mathrm{L}), \mathrm{S}_{i}\end{array}$} & \multirow{2}{*}{$\begin{array}{l}\text { Unit } \\
\text { weightage, } \\
W_{i}\end{array}$} & \multicolumn{2}{|c|}{ Subindex, $Q_{i}$} & \multicolumn{2}{|c|}{$Q_{i} \times W_{i}$} & \multicolumn{2}{|c|}{ Mean HPI } \\
\hline & Rain & Dry & & & Rain & Dry & Rain & Dry & Rain & Dry \\
\hline $\mathrm{Fe}$ & 0.26 & 0.13 & 0.30 & 3.33 & 85 & 44 & 285 & 145 & 70 & 46 \\
\hline $\mathrm{Mn}$ & 0.18 & 0.16 & 0.30 & 3.33 & 61 & 52 & 202 & 174 & & \\
\hline $\mathrm{Zn}$ & 0.16 & 0.07 & 3.00 & 0.33 & 5 & 2 & 2 & 1 & & \\
\hline & & & & 7.00 & & & 488 & 320 & & \\
\hline
\end{tabular}

Fig. 4 HPI values of individual sampling stations compared to heavy metal pollution on the threshold risk $(\mathrm{HPI}=100)$

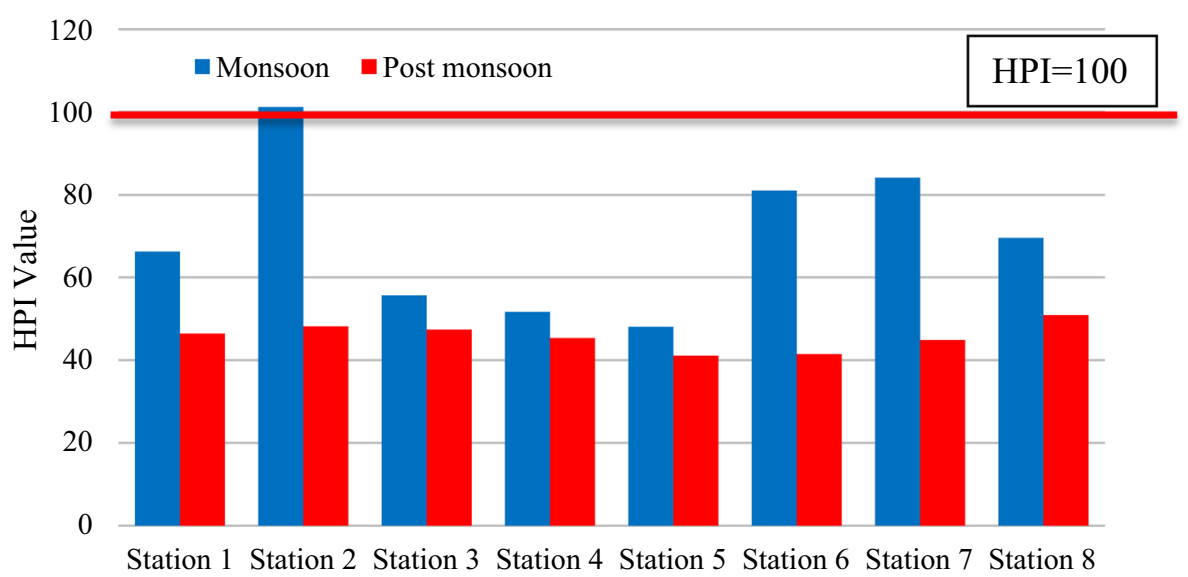


quality is not critically polluted with respect to heavy metals in this village. However, the $\mathrm{pH}$ values of all the samples in both seasons were lower than the Thai permissible limit prescribed for drinking water (Department of Health Standards) and guideline values of WHO (2011). The values of $\mathrm{pH}$ of all sampling stations in the village during the monsoon and post-monsoon seasons were clearly indicated in the unsuitable range for drinking and domestic purpose. Therefore, this area needed adequate preliminary treatment to overcome low $\mathrm{pH}$ problem for drinking and domestic purposes. However, other heavy metals polluted by agricultural activities, such as arsenic, cadmium, and leads were not analyzed in this study. Other important parameters indicated that microbiological quality analysis and heavy metals should be analyzed for drinking purposes to represent the quality of the water supply of this village in the future works.

Acknowledgements The authors acknowledge the Faculty of Sciences and Health Technology, Kalasin University, for providing necessary facilities to carry out the research work. Finally, thanks to the laboratory team and colleagues in Environmental Science and Natural Resources Department.

\section{Compliance with ethical standards}

Conflict of interest This study was supported by Grants from the curriculum of environmental science program in the Faculty of Sciences and Health Technology, Kalasin University. The authors declare no conflicts of interest.

Open Access This article is licensed under a Creative Commons Attribution 4.0 International License, which permits use, sharing, adaptation, distribution and reproduction in any medium or format, as long as you give appropriate credit to the original author(s) and the source, provide a link to the Creative Commons licence, and indicate if changes were made. The images or other third party material in this article are included in the article's Creative Commons licence, unless indicated otherwise in a credit line to the material. If material is not included in the article's Creative Commons licence and your intended use is not permitted by statutory regulation or exceeds the permitted use, you will need to obtain permission directly from the copyright holder. To view a copy of this licence, visit http://creativecommons.org/licenses/by/4.0/.

\section{References}

Agency for Toxic Substances and Disease Registry (2012) Toxicological profile for manganese. U.S. Department of Health and Human Services, Atlanta. https://www.atsdr.cdc.gov/toxprofiles/tp151.pdf

Akram S, Rehman F (2018) Hardness in drinking-water, its sources, its effects on humans and its household treatment. J Chem Appl 4(1): $1-4$

American Public Health Association (2014) Standard method for the examination of water and wastewater. American Public Health Association, Washington

Ardani R, Yari AR, Fahiminia M, Hashemi S, Fahiminia V, Saberi BM (2015) Assessment of influence of landfill leachate on groundwater quality: a case study Albourz landfill (Qom, Iran). Arch Hyg Sci 4(1):13-21
Balakrishnan A, Ramu A (2016) Evaluation of heavy metal pollution index (HPI) of ground water in and around the coastal area of Gulf of Mannar biosphere and Palk Strait. J Adv Chem Sci 2(3):331-333

Beyene HD (2015) Quality analysis of potable water in Dowhan, Erop Wereda, Tigrai, Ethiopia. Chem Mater Res 7(3):93-99

Biswas PK, Uddin N, Alam S, ST S, Ahmed T (2017) Evaluation of heavy metal pollution indices in irrigation and drinking water systems of Barapukuria Coal Mine Area, Bangladesh. Am J Water Resour 5(5):146-151. https://doi.org/10.12691/ajwr-5-5-2

Boulos AZ, Raina H (2015) Heavy metal pollution index for groundwater quality assessment in Damascus Oasis, Syria. Environ Earth Sci 73:6591-6600. https://doi.org/10.1007/s12665-014-3882-5

Chakraborty R, Zaman S, Mukhopadhyay N, Banerjee K, Mitra A (2009) Seasonal variation of $\mathrm{Zn}, \mathrm{Cu}$ and $\mathrm{Pb}$ in the estuarine stretch of West Bengal. Indian J Mar Sci 38(1):104-109

Department of Health (2009) Standard water quality of drinking water supply in Thailand

Erikson KM, Thompson K, Aschner J, Aschner M (2007) Manganese neurotoxicity: a focus on the neonate. Pharmacol Ther 113:369-377

Gurdeep S, Rakesh KK (2017) Heavy metal contamination and its indexing approach for groundwater of Goa mining region, India. Appl Water Sci 7:1479-1485

Hayelom DB (2015) Quality analysis of potable water in Dowhan, Erop Wereda, Tigrai, Ethiopia. Chem Mater Res 7(3):93-99

Jafar AA, Loganathan K, Ananthakrishnan S (2013) A comparative evaluation of groundwater suitability for drinking and irrigation purposes in Pugalur area, Karur district, Tamilnadu, India. Arch Appl Sci Res 5(1):213-223

Kumar PJS, Delson PD, Babu PT (2015) Appraisal of heavy metals in groundwater in Chennai city using a HPI model. Bull Environ Contam Toxicol 89:793-798. https://doi.org/10.1007/s0012 8-012-0794-5

Pradip KB, Nasir U, Sha A, Tamjid US, Sharmin S, Tofayal A (2017) Evaluation of heavy metal pollution indices in irrigation and drinking water systems of Barapukuria coal mine area, Bangladesh. Am J Water Res 5(5):146-151

Prasad B, Bose JM (2001) Evaluation of the heavy metal pollution index for surface and spring water near a limestone mining area of the lower Himalayas. Environ Geol 41(1):183-188

Reddy SJ (1995) Encyclopedia of environmental pollution and control, Environmental media, Karlia, India. 1:342

Reza R, Singh G (2010) Assessment of ground water quality status by using Water Quality Index method in Orissa, India. World Appl Sci J 9(12):1392-1397

Rizwan R, Gurdeep S, Manish KJ (2011) Application of heavy metal pollution index for ground water quality assessment in Angul District of Orissa, India. Int J Res Chem Environ 1(2):118-122

Sarala TD, Uma MT (2013) Metal pollution assessment in ground water. Bull Environ Pharmacol Life Sci 2(12):122-129

Sheykhi V, Moore F (2012) Geochemical characterization of Kor River water quality, Fars Province, Southwest Iran. Water Qual Expo Health 4:25-38

Sirajudeen J, Arul MS, Manivel V (2014) Heavy metal pollution index of ground water of Fathima Nagar area near Uyyakondan Channel, Tiruchirapalli District, Tamilnadu, India. World J Pharm Pharm Sci 4(1):967-975

Sobhanardakania S, Yarib AR, Taghavic L, Tayebid L (2016) Water quality pollution indices to assess the heavy metal contamination, case study: groundwater resources of Asadabad Plain in 2012. Arch Hyg Sci 5(4):221-228

Vasanthavigar M, Srinivasamoorthy K, Gandhi R, Chidambaram S, Vasudevan S (2010) Application of water quality index for groundwater quality assessment: Thirumanimuttur sub-basin Tamilnadu, India. Environ Monit Assess 171(4):595-609 
World Health Organization (2011) Guidelines for drinking-water quality. World Health Organization, Geneva

Zakhem BA, Hafez R (2015) Heavy metal pollution index for groundwater quality assessment in Damascus Oasis, Syria. Environ Earth Sci 73:6591-6600. https://doi.org/10.1007/s12665-014-3882-5
Publisher's Note Springer Nature remains neutral with regard to jurisdictional claims in published maps and institutional affiliations. 